\title{
Case Comment: the unauthorized use of the image of a football player in videogames as a violation of image rights in Brazil
}

(C) Paula Westenberger, 2018. The definitive, peer reviewed and edited version of this article is published in Interactive Entertainment Law Review, volume 1, issue 2, pages 119-122, Dec 2018, available at < https://doi.org/10.4337/ielr.2018.02.05>

Keywords: Brazil; Football player; Fundamental rights; Image rights; Videogame.

\begin{abstract}
This case comment analyses a decision by the São Paulo Court of Appeal in a case concerning whether the use of the image of a football player in a videogame, without the athlete's permission, constituted a violation of his image rights. The Court of Appeal found that the use of the image of a public person, without their consent, in a commercial activity with no relevant public interest to be protected, harms a fundamental personality right and generates the right to compensate for damages.
\end{abstract}

\section{Introduction}

This case concerned a claim by football player Leandro Fahel Matos (also known as Fahel), who alleged that the defendants, videogame developers Konami Digital Entertainment, ${ }^{1}$ had unduly used his image and personal characteristics in the 2013, 2014, 2015 and 2016 editions of the game "Pro Evolution Soccer", as they had

\footnotetext{
${ }^{1}$ The claim was brought against Konami Digital Entertainment Co Ltd, Konami do Brasil Ltda and Konami Digital Entertainment Inc, who belong to the same economic group, but only the first company offered a defence, see TJSP, proceeding no. 1126481-26.2016.8.26.0100, Judge Rodrigo Cesar Fernandes Marinho, decided on 27 August 2017, fls 557.
} 
not obtained his authorization. ${ }^{2}$ The defendant alleged that they had obtained the required licences from FIFPro $^{3}$ and from the club Esporte Clube Bahia, and also argued that the claimant was not featured in the 2015 and 2016 editions of the game. ${ }^{4}$

The first instance decision found in favour of the claimant in relation to the 2013 and 2014 editions of the game, which were the editions where the first instance judge had found that the defendants had used the image and personal characteristics of the player, by having used the same name, nickname and physical characteristics of the claimant, as well as making an express link with the club Esporte Clube Bahia, thus resulting in an unequivocal identification of the claimant in the game. ${ }^{5}$

According to the first instance judge, the use of image rights can only be authorized by the athlete, thus it was irrelevant that the defendant had obtained a licence from FIFPro, who was not a representative of the athlete. ${ }^{6}$ The judge based his decision on article 87-A of Law No. 9.615 of 1998 (also known as "Lei Pelé", or "Pelé Law") ${ }^{7}$, which establishes that:

\footnotetext{
${ }^{2}$ TJSP, proceeding no. 1126481-26.2016.8.26.0100, Judge Rodrigo Cesar Fernandes Marinho, decided on 27 August 2017, fls 556.

${ }^{3}$ FIFPro is an international organization representing professional football players worldwide $<$ https://www.fifpro.org/en/about-fifpro/about-fifpro> accessed 19 September 2018.

${ }^{4}$ TJSP, proceeding no. 1126481-26.2016.8.26.0100, Judge Rodrigo Cesar Fernandes Marinho, decided on 27 August 2017, fls 556.

${ }^{5}$ TJSP, proceeding no. 1126481-26.2016.8.26.0100, Judge Rodrigo Cesar Fernandes Marinho, decided on 27 August 2017, fls 557.

${ }^{6}$ TJSP, proceeding no. 1126481-26.2016.8.26.0100, Judge Rodrigo Cesar Fernandes Marinho, decided on 27 August 2017, fls 558.

${ }^{7}$ See the WIPO-Lex entry for this piece of legislation $<$ http://www.wipo.int/wipolex/en/details.jsp?id=16222> accessed 27 September 2018. See also Camargo de Carvalho, A. J. "Brazil" in Gurovits, A. (ed) The Sports Law Review (Law Business Research, 2015) $27-38$, available at

$<$ http://www.pinheironeto.com.br/Documents/Artigos/Brazil\%20chapter\%20in\%20The\%20Sports\%20 Law\%20Review.pdf> accessed 27 September 2018.
} 
"The right to use the image of the athlete may be assigned or exploited by the athlete upon contractual arrangement of a civil nature and securing rights, duties and conditions distinct from the special contract of sports work. (Included by Law No. 12.395 of 2011)."8

The judge noted that the defendant did not prove the existence of a contract with the club Esporte Clube Bahia that included an assignment of the right to exploit the image of the athlete, not to be confused with the so-called "arena right" established by art 42 of the Pele Law, i.e. the exclusive prerogative of a sports entity to negotiate, authorize, or prohibit the capture, fixation, emission, transmission, retransmission or reproduction of images, by whatever means, of a sport event where the athletes participate. ${ }^{9}$ Therefore, the football club was also not entitled to authorize the use of the image of the athlete. ${ }^{10}$

In relation to the 2015 and 2016 editions, however, the first instance judge found that there had been no use of the image of the athlete, as even though the player "Filbena" had the same characteristics and club affiliation as the claimant, he could not be confused with the claimant and the claimant's sports nickname. ${ }^{11}$

The claimant had claimed damages in the amount of $\mathrm{R} \$ 25.000,00$ for the 2013, 2015 and 2016 editions, and of 5\% of the net revenue with the sales of the 2014 edition in Brazil. The judge, however, awarded damages in the total amount of R\$

\footnotetext{
${ }^{8}$ English translation by the author.

${ }^{9}$ Art 42, Law No. 9.615 of 1998 (Pelé Law).

${ }^{10}$ TJSP, proceeding no. 1126481-26.2016.8.26.0100, Judge Rodrigo Cesar Fernandes Marinho, decided on 27 August 2017, fls 558.

${ }^{11}$ TJSP, proceeding no. 1126481-26.2016.8.26.0100, Judge Rodrigo Cesar Fernandes Marinho, decided on 27 August 2017, fls 558.
} 
$25.000,00$ (approximately $£ 4,800.00)^{12}$, where $\mathrm{R} \$ 10.000,00$ related to the 2013 edition and $\mathrm{R} \$ 15.000,00$ to the 2014 edition. The judge did not grant damages based on net revenue, but awarded a higher amount in relation to the 2014 edition as the player's image had also been displayed on the cover of the game on that edition. The damages award aimed at providing a reasonable compensation, avoiding unjust enrichment, and considering the particularities of the case, in particular the seriousness and repercussions of the use of the claimant's image. ${ }^{13}$

Both claimant and defendant appealed. The first alleged that his image had also been used in the 2015 and 2016 editions of the game, but in a disguised manner, by changing only the name of the player, but not his physical characteristics and individual characteristics as a player. ${ }^{14} \mathrm{He}$ also requested the increase of the damages award, considering he was a public person who also used his image for advertising purposes, and also considering the use of his image on the cover of the 2014 edition alongside only other 19 players (in a game containing approximately 15,000 players). According to the claimant, it was not fair that the defendant would pay millions of Brazilian Reais (BRL or R\$) to players such as Neymar but nothing for other players, and that his request for $5 \%$ of the net revenue was reasonable, as this is what he would have requested if his authorization had been sought. He therefore reinforced his

\footnotetext{
${ }^{12}$ More specifically $£ 4,776.28$ according to the conversion rate at the time of writing, i.e. approximately $1 \mathrm{GBP}=5.23 \mathrm{BRL} ; 1 \mathrm{BRL}=0.19 \mathrm{GBP}:<\mathrm{https}: / /$ www.xe.com> accessed 28 September 2018.

${ }^{13}$ The first instance judge considered three elements: a) the image of the player was used alongside that of other players; b) no harm to the honour of the player occurred; c) the claimant's status of professional athlete. TJSP, proceeding no. 1126481-26.2016.8.26.0100, Judge Rodrigo Cesar Fernandes Marinho, decided on 27 August 2017, fls 556 and 559.

${ }^{14}$ The claimant made reference to the fact that the website pesmaster.com still associated the characters 'Filbena' and 'M Corte Real' on the 2015 and 2016 editions respectively as the player Fahel: TJSP, appeal no. 1126481-26.2016.8.26.0100, rapporteur Judge Rodolfo Pellizari (6th Civil Panel), decided on 8 February 2018, fls 671.
} 
claim for R\$25.000,00 for each of the 2013, 2015 and 2016 editions, and of 5\% of the net revenue with the sales of the 2014 edition in Brazil. ${ }^{15}$

The defendant, in turn, argued that their use of the claimant's image had been duly authorized by FIFPro; that there was a contractual chain of transfer of rights, including by Esporte Clube Bahia, who detained all of the player's image rights; that the image of the claimant was always used alongside other players' images; that the claimant was a public person, associated with sports, which is the heritage of all of Brazilian society, and thus his personality rights should weight less than the public interest; and that in case the first instance decision is maintained, the damages award should be reduced. ${ }^{16}$

\section{The appeal decision}

The appeal decision ${ }^{17}$ essentially maintained the core of the first instance decision, finding that only the player was entitled to authorize the use of his image, ${ }^{18}$ and finding that violation of such rights only occurred in relation to the 2013 and 2014 editions, and not the 2015 and 2016 ones. $^{19}$

\footnotetext{
${ }^{15}$ TJSP, appeal no. 1126481-26.2016.8.26.0100, rapporteur Judge Rodolfo Pellizari (6th Civil Panel), decided on 8 February 2018, fls 671-672.

${ }^{16}$ TJSP, appeal no. 1126481-26.2016.8.26.0100, rapporteur Judge Rodolfo Pellizari (6th Civil Panel), decided on 8 February 2018, fls 673.

${ }^{17}$ TJSP, appeal no. 1126481-26.2016.8.26.0100, rapporteur Judge Rodolfo Pellizari (6th Civil Panel), decided on 8 February 2018.

${ }^{18}$ The licence agreements signed with FIFPro, on their own, did not allow the assumption that there had been authorization by the athlete for the use of his image, nickname and physical characteristics by the defendants on their 2013 and 2014 videogames. Art 87-A of Law No. 9.615 of 1998 (Law Pelé) requires specific written permission by the athlete, which did not exist in this case. The licence agreement between Konami Digital Entertainment Co. Ltd. and Esporte Clube Bahia did not involve an assignment of the image rights of the claimant, but only the so-called "arena right" (see $\mathrm{n} 9$ and corresponding paragraph): TJSP, appeal no. 1126481-26.2016.8.26.0100, rapporteur Judge Rodolfo Pellizari (6th Civil Panel), decided on 8 February 2018, fls 678.

${ }^{19}$ The appeal decision provides a somewhat clearer explanation in that it was not possible to link the claimant's image to the characters of such more recent editions of the game, as the characteristics that
} 
It should be noted that this decision is now under appeal to the Superior Court of Justice (STJ). ${ }^{20}$ However, the Court of Appeal decision already deserves attention, ${ }^{21}$ and important aspects have been discussed in such decision, including on fundamental rights and on the quantification of damages, as will be seen below.

\author{
(a) Fundamental rights
}

The decision highlighted that the right to image (likeness), enjoyed by the athlete, is a personality right, protected as per article $5, \mathrm{~V}, \mathrm{X}$ and $\mathrm{XXVIII}(\mathrm{a})$ of the Brazilian Constitution, ${ }^{22}$ articles 11 and 20 of the Civil Code, ${ }^{23}$ and article $87-\mathrm{A}$ of the Pelé Law. Therefore, this right could only have been assigned to the defendants by the claimant, or by a person or legal entity to which the claimant would have

the claimant argued where personal to him, could actually apply to numerous other players and were thus insufficient to individualize the claimant. TJSP, appeal no. 1126481-26.2016.8.26.0100, rapporteur Judge Rodolfo Pellizari (6th Civil Panel), decided on 8 February 2018, fls 680.

${ }^{20}$ Recurso Especial (Special Appeal) filed on 12 April 2018, protocol No. WPRO.18.00313838-8, currently being processed by the São Paulo Court of Appeal:

$<$ https://esaj.tjsp.jus.br/cposg/show.do?processo.foro=990\&processo.codigo=RI004AW0B0000\#?cdD ocumento $=18>$ accessed 28 September 2018.

${ }^{21}$ This decision has been subject to commentary in Brazil by relevant legal practice news outlets, e.g.: Murta Goyanes (law firm), "Hot Topic - Use of image of a professional soccer player in a video game" (Murta Goyanes, 26 February 2018) <http://www.murtagoyanes.com.br/en/noticias/hot-topic-use-ofimage-of-a-professional-soccer-player-in-a-video-game/>; Martines, F "Criadora de games indenizará ex-zagueiro do Bahia que teve imagem usada em jogo" (Conjur, 18 February 2018)

$<$ https://www.conjur.com.br/2018-fev-18/criadora-games-indenizara-ex-zagueiro-imagem-usada-jogo> accessed 28 September 2018.

${ }^{22}$ English version of the Constitution of the Federative Republic of Brazil of 1988 available at $<$ http://english.tse.jus.br/arquivos/federal-constitution> accessed 28 September 2018.

${ }^{23}$ Lei 10.406 of 2002 ("Civil Code"):

Art. 11. "Except in the cases provided by law, personality rights are non-transferrable and irrevocable, and its exercise cannot suffer a voluntary limitation."

Art. 20. "Except if authorized, or if necessary to the administration of justice or the maintenance of public order, the divulgation of writings, the transmission of the word or the publication, exhibition or use of the image of a person may be prohibited, as per their request and without prejudice to the idemnification that may be applicable, if it harms their honour, good fame or respectability, or if destined to commercial aims. (See ADI 4815). Single paragraph. In relation to the dead or absent, the spouse, ascendents or descendents will be legitimate parties to request this protection."

English translation by the author. Portuguese version available at

$<$ http://www.planalto.gov.br/ccivil_03/leis/2002/L10406.htm> accessed 27 September 2018. 
unequivocally assigned this right. $^{24}$

According to the Court of Appeal, the fact that the athlete was a public person, as argued by the defendant, did not result in his image right being public, and neither it allowed that the use of his image without his permission would go without consequences, particularly for commercial purposes. ${ }^{25}$

The Court of Appeal made reference to a decision by the Brazilian Constitutional Court (STF) ${ }^{26}$ to highlight that even though requiring prior authorization for the use of one's image would constitute an inadmissible form of censorship, the user could still be liable to pay compensation, a posteriori, if the use "harms their honour, good fame or respectability, or if destined to commercial aims. $" 27$

However, and importantly, the Court of Appeal stressed that this particular case did not involve a conflict of fundamental rights, for example between image rights and freedom of expression or of the press, which would require a balancing exercise. The case in hand, according to the Court of Appeal, merely concerned the commercial exploitation of the image of the claimant, protected as a fundamental right, which had economic value in the commercial activity of the defendants, consisting of the development and commercialization of videogames, which was an

\footnotetext{
${ }^{24}$ TJSP, appeal no. 1126481-26.2016.8.26.0100, rapporteur Judge Rodolfo Pellizari (6th Civil Panel), decided on 8 February 2018, fls 676.

${ }^{25}$ TJSP, appeal no. 1126481-26.2016.8.26.0100, rapporteur Judge Rodolfo Pellizari (6th Civil Panel), decided on 8 February 2018, fls 676-677.

${ }^{26}$ STF, ADI 4815/DF, rapporteur Justice Cármen Lúcia, decided 10 June 2015. In this decision, the Brazilian Constitutional Court (STF) concluded that prior authorization was not required for biographies, based on a balance of fundamental rights including freedom of expression and image rights. The prior understanding that authorization was required stemmed from an interpretation of arts 20 and 21 Civil Code 2002 that the STF deemed unconstitutional.

${ }^{27}$ This is actually the wording of article 20 of the Civil Code, see $n 23$.
} 
activity that, unlike argued by the defendants, did not involve any public interest to be protected. $^{28}$

With this statement, the Court of Appeal appears to have arguably too widely dismissed the possibility of protection of videogames by fundamental rights such as freedom of expression. ${ }^{29}$

(b) Quantifying damages

The Court of Appeal found that the economic value of the image of the claimant, considering how well known he was and his importance in the videogame as a whole (he featured amongst thousands of other players) were factors to be considered in order to quantify the damages. ${ }^{30}$

The Court of Appeal noted, however, that it was not appropriate to consider the total profits of the sales of the game, which also included the images of other players with various degrees of fame, and thus also contributed to the value of the product. $^{31}$

\footnotetext{
${ }^{28}$ TJSP, appeal no. 1126481-26.2016.8.26.0100, rapporteur Judge Rodolfo Pellizari (6th Civil Panel), decided on 8 February 2018, fls 676-677.

${ }^{29}$ This is arguably in contrast with jurisprudential developments such as the United States, where videogames qualified for protection by freedom of expression: US Supreme Court, Brown v Entertainment Merchants Association 564 U. S. __ (2011).

${ }^{30}$ TJSP, appeal no. 1126481-26.2016.8.26.0100, rapporteur Judge Rodolfo Pellizari (6th Civil Panel), decided on 8 February 2018, fls 678.

${ }^{31}$ TJSP, appeal no. 1126481-26.2016.8.26.0100, rapporteur Judge Rodolfo Pellizari (6th Civil Panel), decided on 8 February 2018, fls 680. In this respect, the court noted the defendant's argument that the claimant represented only $0,006 \%$ of the total of players in the game (more than 15,000 ). The court also noted it would be absurd to grant a percentage over the total profits of the defendant with the sale of all its products, including other products that did not relate to this case.
} 
The Court considered that the image of the claimant was not as economically valuable as that of other more famous athletes, but it still had some economic value. Even though there had not been harm to his image, reputation or honour, the claimant still had to be compensated for the unauthorized and unremunerated use of his image for commercial purposes. ${ }^{32}$

The criteria applied by the Court of Appeal to quantify the damages award was essentially the same as the first instance, ${ }^{33}$ but with the added consideration of the fact that the defendant was famous worldwide in the videogame sector, with sales reaching U\$ 2,2 billion between April 2015 and March 2016. ${ }^{34}$

In view of this, the Court of Appeal increased the damages award to a total of $\mathrm{R} \$ 35,000$ (approximately $£ 6,700.00$ ), ${ }^{35}$ where R $\$ 10,000$ corresponded to the 2013 edition and $R \$ 25,000$ to the 2014 edition, where the player's image featured on the cover of the game. ${ }^{36}$

\section{Related jurisprudence and conclusion}

Another aspect worth noting about this decision is the reference to a number of decisions in a similar vein, showing that this case is not an isolated example of the

\footnotetext{
32 TJSP, appeal no. 1126481-26.2016.8.26.0100, rapporteur Judge Rodolfo Pellizari (6th Civil Panel), decided on 8 February 2018, fls 681.

${ }^{33}$ See (n 13).

34 TJSP, appeal no. 1126481-26.2016.8.26.0100, rapporteur Judge Rodolfo Pellizari (6th Civil Panel), decided on 8 February 2018, fls 683.

${ }^{35}$ More specifically $£ 6,686.48$, according to the conversion rate at the time of writing, i.e. approximately $1 \mathrm{GBP}=5.23 \mathrm{BRL} ; 1 \mathrm{BRL}=0.19 \mathrm{GBP}:<\mathrm{https}: / /$ www.xe.com $>$ accessed 28 September 2018.

36 TJSP, appeal no. 1126481-26.2016.8.26.0100, rapporteur Judge Rodolfo Pellizari (6th Civil Panel), decided on 8 February 2018, fls 683-684 and 688.
} 
need for authorisation by athletes for the use of their image on videogames, but likely yet another decision that may add to a growing body of case law from the São Paulo Court of Appeals on this matter. ${ }^{37}$

It is clear in these precedents that FIFPro licences, and even licences by the sports clubs, do not allow a videogame developer to use the image of an athlete in Brazil, and evidence of specific authorization by the athlete is required. The possibility remains available to videogame developers to sue FIFPro or the relevant sports club for licensing a right they did not have, if that was the case. ${ }^{38}$

It is also noted that this decision was in line with the damages award of $\mathrm{R} \$$ $10.000,00$ per game that had been previously adopted in the case law, while an increase in damages in relation to one of the editions was owing to the fact that the image of the athlete had also been used on the cover of the game.

\footnotetext{
${ }^{37}$ Relevant case law by the São Paulo Court of Appeal regarding the videogames "FIFA Soccer" and "FIFA Manager" include: TJSP, appeal no 1048082-17.2015.8.26.0100, rapporteur Judge Fábio Podestá (5th Civil Panel), decided on 14 December 2016 (this case involved player Gonzalo Fierro and EA Sports Electronic Arts); TJSP, appeal no 1054427-96.2015.8.26.0100, rapporteur Judge Donegá Morandini (3rd Civil Panel), decided on 31 January 2017 (this decision involved player Wellington Pereira do Nascimento, known as Wellington Paulista, EA Sports Electronic Arts and the clubs Cruzeiro and Criciúma); TJSP, appeal no. 1062611-41.2015.8.26.0100, rapporteur Judge Marcia Dalla Déa Barone (3rd Civil Panel), decided on 27 June 2017 (this case involved player Omar Constante Reis Santos and EA Sports Electronic Arts. The judge reduced the damages award from R $\$ 50.000,00$ to R\$ $10.000,00$, as the violation of the image rights had only occurred in one edition of the game); and TJSP, appeal no. 1126620-46.2014.8.26.0100, rapporteur Judge Donegá Morandini (3rd Civil Panel) decided on 29 August 2017 (this case involved player Henrique Almeida, EA Sports Electronic Arts Ltda. and São Paulo Futebol Clube, and concerned three editions of each of the games. The Court of Appeal considered the approach of the Court in similar cases to award damages in the amount of R\$10.000,00, per game, amounting a total of R $\$ 60.000,00$ in damages); TJSP, appeal no 106269372.2015.8.26.0100, rapporteur Judge Piva Rodrigues (9th Civil Panel), decided on 6 March 2018 (this case involved player Emerson Santos, EA Sports Electronic Arts and the club Grêmio, and maintained the first instance award of damages in the amount of $R \$ 10.000,00$, per game, amounting a total of $R \$$ $60.000,00$ in damages for a total of six games, based on the approach in the existing case law).

${ }^{38}$ See for example, TJSP, appeal no. 1126481-26.2016.8.26.0100, rapporteur Judge Rodolfo Pellizari (6th Civil Panel), decided on 8 February 2018, fls 680; and TJSP, appeal no. 113111905.2016.8.26.0100, rapporteur Judge Maia da Cunha (4th Civil Panel), decided on 22 March 2018, fls 2048.
} 
Particularly interesting in the decision analysed in this case comment was the statement on the absence of a public interest in relation to developing and commercializing videogames, and thus a lack of conflict of fundamental rights. This interpretation had been previously advanced by the São Paulo Court of Appeal in a similar case, ${ }^{39}$ but had not been expressly or consistently considered in other subsequent decisions. ${ }^{40}$ This may arguably be considered an overly broad approach, which denies the coverage of videogames by fundamental rights such as freedom of expression. Perhaps a more balanced approach would have involved the recognition of the applicability of freedom of expression to cover videogames in principle, and a balancing of interests based on the particularities of the case, concluding towards the prevalence of the image rights of the athletes to require the damages award.

It now remains to be seen what will be the decision by the Superior Court of Justice (STJ) on the currently pending appeals, ${ }^{41}$ and whether any further clarification is going to be made in relation to fundamental rights.

\footnotetext{
${ }^{39}$ TJSP; appeal no. 1087117-81.2015.8.26.0100, rapporteur Judge Grava Brazil (8th Civil Panel) decided on 27 September 2017.

${ }^{40}$ Namely those cited in (n 37).

${ }^{41}$ See (n 20). Appeals to the STJ are also pending in the cases cited in (n 37).
} 